\title{
Holoprosencephaly: A Case Study for Communicative and Swallowing Management
}

\author{
Muzeyyen Ciyiltepe* and Zafer Unsal Coskun \\ ${ }^{1}$ Department of Speech and Language Therapy, Anadolu University Faculty of Health Sciences, Turkey \\ ${ }^{2}$ Department of Radiology, Giresun Medical University, Turkey
}

*Corresponding author: Muzeyyen Ciyiltepe, Department of Speech and Language Therapy, Anadolu University Faculty of Health Sciences, Eskisehir, Yunus Emre Campus, Eskisehir, Turkey

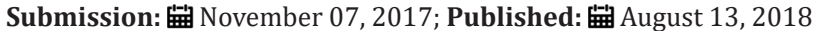

\section{Introduction}

Holoprosencephaly (HP) is a developmental central nervous system defect characterized by advanced facial anomalies resulting from the complete separation of two lobes of the cerebral hemispheres [1]. Prevalence is 1.31 in 10,000 births $[2,3]$. There is a parallel relationship between the combination of different etiological factors in different contributions and the changing clinical picture of the disease. Autosomal dominant and autosomal recessive inherited forms are reported in the literature [4,5]. Considering the studies on holoprosencephaly, developmental, neurological and medical problems were found in children with holoprosencephaly Cohen, 1982; Ersin \& Ertugrul, 2005 [6,7]. Table 1 lists the physical findings that can be seen in individuals with HP. Postnatal care of HP is multidisciplinary, symptomatic and long-lasting cognitive and physical supportive

Table 2: some accompanying problems of HP.. therapy. Prognosis depends on the size of the associated medical and neurological disorders (Table 2).

Table 1: Physical characteristics that can be seen in individuals with HP.

\begin{tabular}{|c|}
\hline Facial Anomalies (cyclopia, etmosephaly) \\
\hline Facial midline defects (premaxillary agenesis) \\
\hline Hyper-Hypo Telorism \\
\hline Cleft palate / lip \\
\hline Microcephaly \\
\hline Straight or pointed nose bridge \\
\hline
\end{tabular}

\begin{tabular}{|c|c|}
\hline Neurocognitive deficits & Diabetus Mellutus \\
\hline Epilepsy & Endoctrin anomalies \\
\hline Recurrent Infections (Aspiration pneumonia) & Major organ malformations (Kardiac problems' kidney problems' etc) \\
\hline Feeding problems & Otonomic nervous system problems (body temprature' heart rithm stability, etc) \\
\hline
\end{tabular}

There are HP and associated complications in the literature. However, in an HP case, language/speech impairment was not observed without dysphagia and craniofacial anomalies [8]. The purpose of this presentation is to share with you the therapeutic approach and results we have accomplished with this rare combination of severe neurocognitive-linguistic pathologies accompanied by severe dysphagia. We studied the case of a 24 month old girl with holoprosencephaly who was admitted to our hospital with difficulty swallowing. Mother was told about the possible problems prior to give birth as seen through ultrasound yet she and her husband chose not to terminate the pregnancy due to their religious beliefs (even though it was guaranteed by her medical primary care physician).
A multidisciplinary study of neurologist, nutritionist and dietician, language and speech therapist was provided during the diagnosis and screening period. Our case was born with a caesarean section at 38 weeks after completing the normal birth process and stayed in the cup for 28 days. It has been learned that she has had long-term jaundice after birth. The birth weight of our case was $2760 \mathrm{gr}$ and the neck was $50 \mathrm{~cm}$. It was seen that the values of life and weight were close to norms when compared with their peers. But the case was microcephaly and the head circumference was $32 \mathrm{~cm}(\mathrm{n}=35 \mathrm{~cm})$. There is no consanguineous marriage in the family history. The head control of the child was weak and could not sit without support. When you want to lift the foot, you have flexion and adduction in the hips, shearing in the legs, knee flexion, 
and an equinovalgus posture in the ankle (Figure 1). It has been reported that the neurological examination is hypotonic and the emanation is weak, standing up. Cranial measurements are below normal. As shown in Figure 2(A-C), section of cranial MR images are compatible with semi lobar holoprosencephaly and have the features of:

A. Cerebral lobes are present but are fused anteriorly and at the thalami and then is partial diverticulation of the brain,

B. Absence of septum pellucidum,

C. Monoventricle with partially developed occipital and temporal horns,

D. Rudimentary falx cerebri: absent anteriorly,

E. Incompletely form interhemispheric fissure,

F. Fusion of thalami,

G. Agenesis of corpus collosum, and incomplete hippocampal formation.

Further, cavum septum pellucidum has not been observed, Lateral ventriculo-posterior horn width is $10 \mathrm{~mm}$ and choroidal complex increases lateral wall distance. These results were also observed during fetal neurosonography that was also compatible with semi lobar holoprosencephaly. Posterior fossa was normal. At the time of clinical assessment, her eyes were able to follow visual and auditory stimuli. However, Denver Screening Test II Scores in combined with the AGTE (Ankara Developmental Test Inventory) indicated 3 months in general overall development age, 3 months in cognitive-linguistic skills development, 3 months in gross motor skills development in 3 months, and 3 months in social skill and self-care development 1 year and 2 months old. According to the findings of the anamnesis and the clinical evaluation, it was concluded that there was a "delay in cognitive development at a severe level". It was observed that there was an increase in tonus in the lower extremities. It has been also observed that some reflexes are still present even though they are diminished long before with age matched normally developing peers; DTRs live, moro $+/+$, clonus $+/+$, babinski $+/+$. Tongue-trusting was the primary means of bolus propulsion anterio-posteriorly, in that it takes more time and energy and less success with bolus to reach from oral phase to pharyngeal phase to swallow. Her teeth development was also irregular with enabling her to close for biting and chewing. Her palatal arch was also high which effected her palatal reflex to be triggered on a timely fashion.

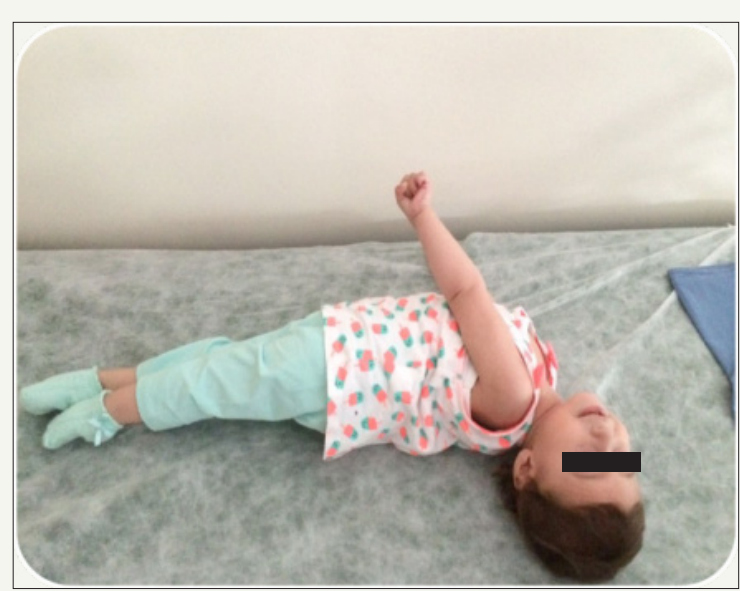

Figure 1: Free stay of the child when lay on the bed.
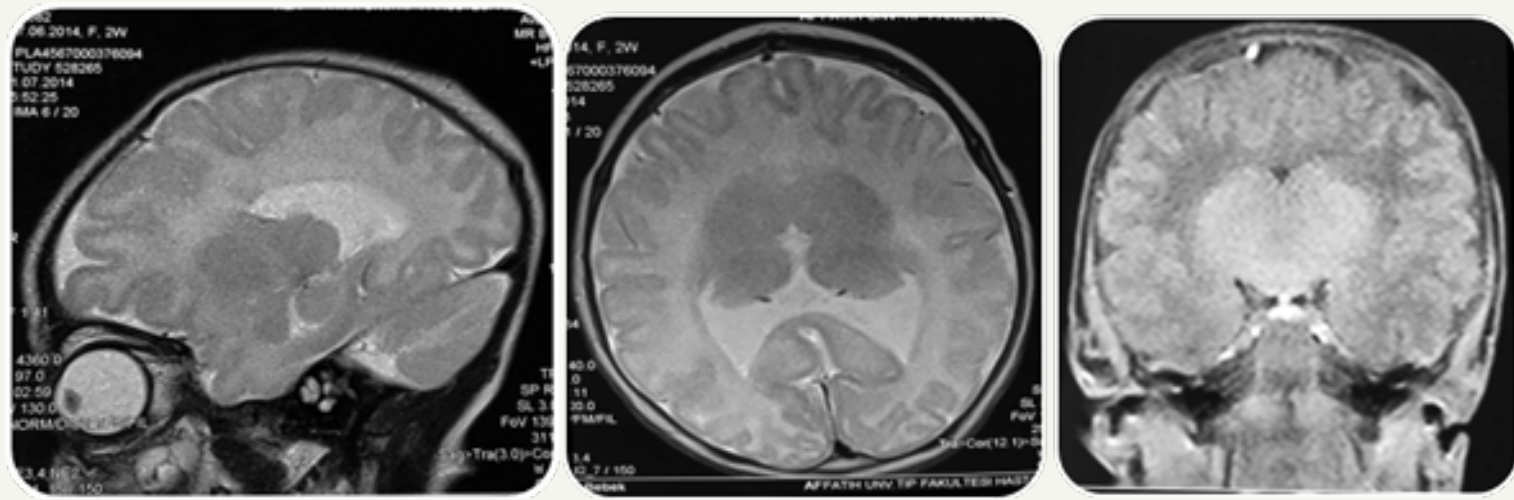

Figure 2: Cranial MR sections of sagittal (A), axial (B) and coronal (C) images. 
The clinic multidisciplinary team management included 6 weeks of therapy per our policy with severe problems as such and then to refer to related services (child life specialist, physical therapist, special education day care centre and dietitian) for continuity of the rehabilitation process. She was seen three times a week for 2, 5 hours/week to one-to-one therapy. Therapy focused on following directives, produce primary sounds that are toward age appropriate sounds (from vocalizations to start with), stay on focus and keep focus for 5-10 minutes, and decrease meal time with advancing bolus consistencies toward age appropriate level; such as, introducing different flavours other then milk, yoghurt and pudding. Implemented taping her face (Figure 3), thermaltactile stimulation of facial pillars and neuro-electro stimulation of cricohyoid area as well as facial musculatures. Below table shows before and after status of 18 visits of intervention (Table $3,4)$. Knowing that it was not possible to make the differences to be normalized in this child, her family was very pleased with the changes in her over all improvement. They indicated that taking her out, playing with her socially and able to feed her without too much stress changed their quality of life (Table 5).

Table 3: Changes observed with therapy in the areas of speech/language.

\begin{tabular}{|c|c|c|}
\hline Speech/Language & Before Therapy & After Therapy \\
\hline First sounds & $\begin{array}{l}\text { None (some weak vocals during laughing but not } \\
\text { consistant }\end{array}$ & Vovels /ah, o, i and e/ with imitative cueing \\
\hline Eye contact & $\begin{array}{l}\text { Just for parents and some relatives that visits } \\
\text { frequently }\end{array}$ & $\begin{array}{l}\text { Clinicians and caregivers during therapy and medical } \\
\text { care }\end{array}$ \\
\hline Attention span & Not present & Able to focus and keep it for 10 minutes ongoing \\
\hline $\begin{array}{l}\text { Gesture development/use for communi- } \\
\text { cation }\end{array}$ & Smile `happy face` & $\begin{array}{l}\text { Smile, look for/search for, sorry/frawn (imitation of } \\
\text { facial expressions) }\end{array}$ \\
\hline
\end{tabular}

Table 4: Swallowing.

\begin{tabular}{|c|c|c|}
\hline Swallowing & Before Therapy & After Therapy \\
\hline Oral-motor & Just palpational tongue movement, no lip closure & $\begin{array}{c}\text { Started to close mouth, began to receivr food from the spoon } \\
\text { and liquids fron a nosey cup }\end{array}$ \\
\hline $\begin{array}{l}\text { Bolus and saliva } \\
\text { control }\end{array}$ & $\begin{array}{l}\text { Very poor, drooling severely, has saliva burns around lower } \\
\text { lip especially }\end{array}$ & $\begin{array}{l}\text { Better saliva management, saliva burns lessened, bolus can } \\
\text { stay in the mouth }\end{array}$ \\
\hline Bolus formation & Not present, using syringe feed & $\begin{array}{l}\text { Started to hold bolus in the mouth, less leakge with puree } \\
\text { consistency }\end{array}$ \\
\hline Meal completion time & $150 \mathrm{cc}$ for 1,5 hour & $150 \mathrm{cc}$ for 30 minutes \\
\hline $\begin{array}{l}\text { Meal consistency } \\
\text { (solids) }\end{array}$ & Puding & Puree with some texture of soft mechanical consistencies \\
\hline Liquid consistency & Pudding & Nectar \\
\hline
\end{tabular}

Table 5: Quality of life.

\begin{tabular}{|l|c|c|}
\hline Family Perception & Before Therapy & After Therapy \\
\hline Quality of Life Score & Moderate level & 53 \\
\hline Beck Depression Score & (score of 20) & Mild level \\
\hline
\end{tabular}

To conclude, an intensive therapeutic intervention makes quality of life better for both family and the child's sake. It is a win-win situation for being able to do things more with their child since feeding time is considerately lessened, the family is learned how to interact with the child as seen in the Figure 2 (A-C) so that her vocalizations could be more productive turning into a communication style (sign plus some sounds and gestures in the future). Further therapeutic arrangements is also made that the family knows seating and positioning is need to be taken care of as well as the early child special education is a must for cognitive development. 


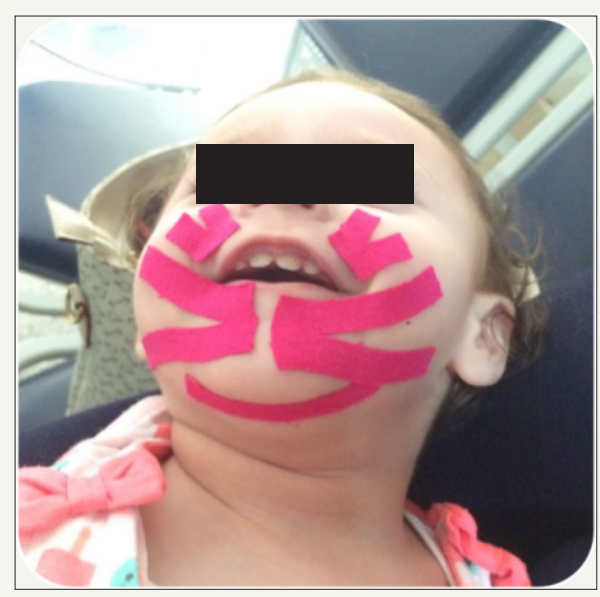

Figure 3: Taping of the facial muscles for lip closure and tongue mobility.

\section{References}

1. Golden JA (1998) Holoprosencephaly: A defect in brain patterning. Neuropathol Exp Neurol 57: 991-999.

2. Kahyaoglu S, Tasdemir Ü, Kaymak O, Timur H, Danıșman N (2013) Semilobar holoprozensefalide yeni bir bulgu olarak bilateral koroid pleksusta yariklanmasi olan 25 haftalik bir fetüsün prenatal tanisi: bir olgu sunumu. Acıbadem Üniversitesi Sağlık Bilimleri Dergisi Cilt 4(4): 201-2014.

3. Calıșkan E, Öztürk N, Kaplan M, Dölen İ, Kandemir Ö, et al. (2004) Semilobar holoprozensefali: Olgu sunumu. Kadın Doğum Dergisi 2: 292293.

4. Cohen MM (2001) Problems in the definition of holoprosencephaly. Am J Med Genet 103(3): 183-187.
5. Croen LA, Shaw GM, Lammer EJ (1996) Holoprosencephaly: Epidemiologic and clinical characteristics of a California population. Am J Med Genet 64(3): 465-472.

6. Ersin N, Ertuğrul F, Saraç A, Aydoğdu S, Olgu BS (2005) Holoprozensefali, Ege Tıp Dergisi 44(3): 183-186.

7. Cohen MM (1982) An update on the holoprosencephalic disorders. The Journal of Pediatrics 101: 865-869.

8. Dubourg C, Bendavid C, Pasquier L, Henry C, Odent S, et al. (2007) Holoprosencephaly. Orphanet J Rare Dis 2: 8.
Creative Commons Attribution 4.0 International License

For possible submissions Click Here

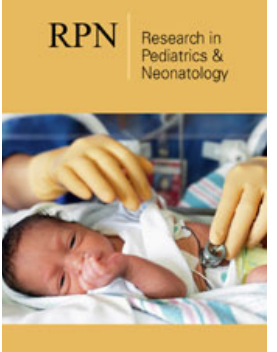

Research in Pediatrics \& Neonatology

\section{Benefits of Publishing with us}

- High-level peer review and editorial services

- Freely accessible online immediately upon publication

- Authors retain the copyright to their work

- Licensing it under a Creative Commons license

- Visibility through different online platforms 